\title{
How dialogues facilitate high school students' responses to poetry
}

\author{
Daniela Cavalli \\ University of Pennsylvania
}

(Text received 30 de May 2019; accepted 26 June 2019; final version 10 July 2019)

DOI: https://doi.org/10.5565/rev/jt13.844

Resum: A partir dels resultats d'un estudi de cas sobre respostes a la poesia en una escola secundària pública de Catalunya, aquest article mostra com el diàleg va facilitar les experiències estètiques d'estudiants de secundària. L'estudi ensenya com converses un a un i en petits grups ocorregudes en situació d'entrevista -i en connexió amb l'activitat de la classe- van mediar aquestes respostes. Per a entendre la mediació dialògica $\mathrm{i}$ les possibilitats que els poemes ofereixen en l'activitat de l'estudiant-lector, l'anàlisi realitzada connecta la visió de la lectura literària com a activitat sociocultural amb la teoria de la recepció lectora i el seu estudi empíric. Els resultats mostren que en l'activitat de construcció de sentit conjunta, els estudiants (a) viuen experiències emocionals $i$ (b) responen a recursos poètics distintius que, al seu torn, creen oportunitats per a (c) la seva literacidad poética i (d) el seu desenvolupament ideològic (ideological becoming, Bajtín, 1981).

Paraules clau: poesia; diàlegs; recepció del lector; escola secundària

\begin{abstract}
Drawing from a case study on students' responses to poetry in a Catalan public high school, this article shows how dialogues facilitate students' aesthetic experiences. The study sheds light on how one on one, and small group conversations that occurred in interview situations -in connection with classroom activity- mediated these responses. As a way to understand dialogical mediation and the affordances of poems in student-reader activity, the analysis connects a sociocultural understanding of literary reading to readers' response theory and its empirical study. Results show that in joint meaning-making activity students (a) live through emotional experiences and (b) respond to distinctive poetic devices, which, in turn, create opportunities (c) for their poetic literacy, and (d) ideological becoming (Bakhtin, 1981).
\end{abstract}

Keywords: poetry; dialogues; reader's response; high school 
Resumen: A partir de los resultados de un estudio de caso sobre respuestas a la poesía en una escuela secundaria pública de Cataluña, este artículo muestra cómo el diálogo facilitó las experiencias estéticas de estudiantes de secundaria. El estudio enseña cómo conversaciones uno a uno y en pequeños grupos ocurridas en situación de entrevista -y en conexión con la actividad de la clase- mediaron estas respuestas. Para entender la mediación dialógica y las posibilidades que los poemas ofrecen en la actividad del estudiante-lector, el análisis realizado conecta la visión de la lectura literaria como actividad sociocultural con la teoría de la recepción lectora y su estudio empírico. Los resultados muestran que en la actividad de construcción de sentido conjunta, los estudiantes (a) viven experiencias emocionales y (b) responden a recursos poéticos distintivos que, a su vez, crean oportunidades para (c) su literacidad poética y (d) su desarrollo ideológico (ideological becoming, Bajtín, 1981).

Palabras clave: poesía; diálogos; recepción del lector; escuela secundaria

\section{Objectives}

In the Catalan context, scholars have worked towards the consolidation of a field of research centered in the education of the literary reader (Colomer, 1991, 1996; Mendoza, 2004; Munita, 2017). There has been a growing interest in the empirical study of the student-reader, which has focused on reading habits of narrative texts (Aliagas, 2011; Colomer 2008, 2009; Manresa, 2007, 2009, 2012; Munita, 2014; Reyes, 2011). Recently the literature has recognized the need to start looking at literary discussions as a mediational mean for literary learning (Munita, 2017). On the other hand, besides some research on outside-of-school poetry writing, and spoken word performance (Aliagas, Fernández, Llonch, 2016; Sanz, 2011), students' responses to poetry have been scarcely studied.

The collective case study from which this article draws had the purpose of contributing to the field centered in the education of the literary reader ${ }^{1}$ by advancing in the exploration of students' responses to poetry. Specifically, this article aims to show evidence on how poetry and conversations about it offer opportunities to explore meanings about the self and the world, at the same time that they facilitate aesthetic experiences and poetic literacy. This study focuses on students'dialogue-mediated activity for constructing meaning for and from poems.

\section{Theoretical framework}

We use Activity Theory, particularly Wells (2002), to understand the role of mediation through dialogue when the object of teaching and learning is a conceptual one, like in literary reading. As Wells argues, in such activity, the function of signs is not to direct someone's action but "to contribute to the construction and exploration of a 'possible world' (Bruner, 1986) that is 
collaboratively undertaken through successive contributions that the participants make to an emerging co-constructed text" (pp. 49-50). Even though this outcome may not take a material form, it can still impact the material world by enabling the participants to envision new possibilities. Bakhtin's concept of ideological becoming connects with these ideas and stresses the role of dialogic activity in the development of one's view of the world (Bakhtin, 1981; Ball \& Freedman, 2004). With Bakthin, we see that in both actual conversation and mediated communication (like poetry reading), the encounter of people's words makes possible different degrees of assimilation or rejection of their discourses. In the evocation of poems (Rosenblatt, 1978), others' discourses are mediated by the reader without an actual rejoinder, allowing for a more open-ended meaning experience. The response of the reader can also be delayed, and undergo subsequent refinement, which enables mediation of the reader meaning-making activity.

In the process of assimilation or rejection of others' discourse, the reader may struggle with poetic discourse at different levels, for example, at an ideological one ${ }^{2}$, as pointed above. $\mathrm{He} /$ she can also struggle while organizing the elements of poetic discourse into a coherent experience to make sense of it (Harker, 1994; Rosenblatt, 1978). The particularities of poetic discourse, or the expectations about it, often pose some challenges to student-readers (EvaWood, 2008). Literary scholars have debated extensively about the specificity of poetic language without reaching conclusive answers. However, it could be said that poetry uses a variety of linguistic strategies and resources to distinct itself from other discursive forms or genres, and at the same time it relies on the reader's expectations. In our study, we understand the particularities of poetry and aesthetic experience mainly drawing from readers' response theory and its empirical study, focusing on two specific phenomena: deviation and increased attention to language and experience. Since Russian Formalism, literary scholars have identified "deviation" as a main characteristic of poetic discourse and other forms of art, explaining its effect on the reader as "defamiliarization" or "dehabituation" (Fawler, 1996; Miall, 2006). Deviation is achieved through different techniques and devices that render the familiar unfamiliar. This, in turn, makes the reader pay attention for a longer period and focus on the lived-through experience (Rosenblatt, 2004; Widdowson, 1992). In her description of aesthetic experience, Rosenblatt argues that deviation is a textual clue that helps readers adopt an aesthetic stance: "an attitude of readiness to focus attention on what is being lived through during the reading event" (Rosenblatt, 2004, p. 1373), which can grant them a more rewarding reading experience. Along these lines, the empirical study of literary reading shows that competent readers activate genre related expectations and relevant world knowledge, at the same time that they pay attention to 
textual devices, which can also yield to their enjoyment of the text (Hanauer, 1998; Peskin, 2010). Furthermore, Miall (2006) adds evidence of emotional response as the driving force of reading.

\section{Methods}

We used qualitative methods to collect, generate and analyze data with an ethnographic approach (Woods 1986; Cambra 2003). Field work was done over five months, and data was gathered and constructed through field notes, class recordings, class materials, in-depth interviews, and emails. The analysis was an inductive, grounded, and iterative process. It included thematic analysis, and elements from discourse analysis. Two main categories for understanding the role of dialogue as mediational tool for the development of students' poetic literacies emerged from coding: (1) meaning exploration that facilitates sign meaning development ${ }^{3}$ (in respect to the reader, her or his world, and poetry); and (2) meaning exploration that encounters deviation and perceives it as an obstacle.

\section{Data sources}

The study was conducted in a Spanish Language and Literature class in a public high school that serves middle-class and working-class families in Sant Cugat del Vallès, a town in the province of Barcelona. It focused on three $10^{\text {th }}$ graders: Huma, Jaime and Ariadna, who were chosen because they were the students who collaborated more often and more eagerly in the study, allowing us to gather more data about them. They volunteered to participate in the interviews conducted outside of the classroom more often than other students and engaged in email communication with the researcher as well.

Huma belongs to an immigrant working-class Moroccan family. At the time of the study, her father was unemployed, and her mother didn't work. Her first language is Bereber', but she also speaks Catalan with her sisters, and Spanish with her friends. Jaime also belongs to a working-class family, but from Andalusian descent. His parents are divorced, and he lives with his mother, who works as a cleaning lady. Ariadna comes from a middle-class Catalan family. Her father is a History high school teacher and a union leader, and her mother is a journalist. Huma's and Jaime's grades in their Spanish class class were below average, and Ariadna's were excellent. Ariadna was very critical of social and cultural establishment, but was still interested in canonic cultural manifestations, including poetry. She was very participative in discussions, at the same time that had difficulties collaborating with classmates. 
Huma, also a participative and responsible student, partnered easily with others for work. Jaime had friends but was reluctant to join them for work. His participation in the classroom tended to be antagonistic and showed lack of motivation.

The teacher of the class, Luisa, was looking for a change in her approach to poetry 5 . She saw the study as an opportunity to do so, and to help students find emotional or meaningful connections with literature. In the unit she planned, she presented canonic (e.g. Generation of 98 and 27) and non-canonic poems (e.g. visual poetry) and gave students the possibility of selecting poems from various sources. Class observations ended when the poetry unit was completed, and were followed by voluntary interviews to students, conducted by the researcher. There was continuity between Luisa's approach to poetry in her classes and the researcher's approach during the interviews.

\section{Results}

Results show that the reading of poetry, and the joint meaning-making activity with the researcher and peers gave students opportunities for poetic literacy, as well as for developing their ideas and stances about the world (ideological becoming). Lived through emotions and response to distinctive poetic devices had an important role in enabling fulfilling aesthetic experiences. In students' conversations with the researcher, dialogue had a mediational role. It scaffolded (Wood, Bruner, \& Ross, 1976) their constructions of meaning, and at the same time it provided prompts for literary learning. The researcher assumed a teaching role in which meaning, and knowledge were treated as open and ongoing constructions (Nystrand, 1997). Her purpose was to facilitate students' exploration of meaning, and their aesthetic positioning (Rosenblatt, 1978).

During an interview, Huma selected and read the poem "Límites".

By Juan Gelman (Argentina 1930- Mexico 2014)

\section{LÍMITES $^{6}$}

¿Quién dijo alguna vez: hasta aquí la sed, hasta aquí el agua?

¿Quién dijo alguna vez: hasta aquí el aire, hasta aquí el fuego?

¿Quién dijo alguna vez: hasta aquí el amor, hasta aquí el odio?
LIMITS
Who once said: thirst up to here, water up to here?
Who once said: air up to here, fire up to here?
Who once said: love up to here, hate up to here?
Who once said: man up to here, up to here no?

¿Quién dijo alguna vez: hasta aquí el hombre, hasta aquí no? 
Sólo la esperanza tiene las rodillas nítidas. Sangran.
Only hope's knees are clear.

They bleed.

Her initial dialogue with the researcher showed that Huma didn't have difficulties evoking the poem (Rosenblatt, 1978) and talking about the meaning she was constructing. She explained that she selected it because of what she felt. The questioning of the first four stanzas resonated on her, as she saw it as a critique of the imposition of arbitrary limits. She contrasted people's limits to her own in an abstract manner. Then, prompted by the researcher she deepened into her emotional response developing a critical stance, and reflecting on her vital experience. The voice perceived in the poem helped her raise a question relevant to her life. By saying "to be raised different from others" she pointed at her situation as a discriminated minority. Her discourse suggests that she was living through a meaning and emotional experience.

Researcher: and the poem when you read it or I read it to you in the first place $\backslash$ what would you say happens to you? does it make you feel anything? does it make you think about something? [ee] does it make you reflect? what what does it do to you? let's say

Huma: $\quad$ it is as if it made me I mean a little bit to reflect because [em] in a way you are right I mean why I don't know why I have started I mean it has come to my mind the example why they say that if a person (???) for you maybe for one for everyone that that is love maybe it's not love $\backslash$ or maybe for you love is different $\backslash$ it is up to that pers that is your feeling that you love him not that he attracts you $\backslash$ and for example if in the thirst and the water part so for example if why up to here is thirst and here and up up to here is water $\backslash$ for example for you one because they tell you when you have your mouth dehydrated $\backslash$ that's thirst $\backslash$ maybe you don't feel that it is thirst/ maybe when you feel thirsty is when you don't you have been raised I don't know different from the others $\backslash$ why do we always have to be as if we were all the samel ${ }^{7}$

The conversation continued with Huma moving into the consideration of unexamined segments of the poem. Deviation in some features struck her. She realized that there were changes in the repetition and questioning patterns. The last stanza challenged her.

Huma
yes it is as if somehow | I think he is kinda outraged saying but who said so? you know/
because each one is free to | I mean to mark his limits each one his limits are different from
other people but he is like he is asking I mean who was the one who set let's say the limit of
this/ like this (...) that he goes on repeating and gives a sonority $\backslash$ but what I don't understand
is [laughing] the last
Researcher $\quad$ you don't understand the last lines?
Huma

Later, she described the impact of deviation and its dehabituating effect using a physical metaphor.

Huma: $\quad$ yes because when the first time that I read it well I understood this then when I read the last line well I felt like out of place $\backslash$ but what what does he want to tell me now 
Huma opened a space for the researcher's help by recognizing that she encountered an obstacle. The researcher started her mediation elaborating on the deviation identified by Huma. The researcher continued by scaffolding Huma's lexical difficulties, clarifying the meaning of the word "nítidas". Also, they looked at the semantic deviation entailed in leaving the subject of "sangrar" (to bleed) implicit, which allowed them to move into a joint exploration of meaning that enriched the understanding of the object for both speakers (Wells, 2002). This dialogue also made possible the implicit mediation (Wertsch, 20079) of literary knowledge. For instance, Huma's picking up on the trope "personification" suggests that this dialogue was also a poetic literacy opportunity.

Huma: $\quad$ yes I mean well that so what you say that hope I mean it is as if hope also has limits no? because you sa you also hope can I mean I have hope that that mor more I mean here it's saying that hope also has limits $\backslash$ because no longer it isn't the hope of going beyond the limits but even that hope when you expect something you expect it within the limits

Researcher: [mjm] of certain limits $\backslash$ yes yes $\backslash$ and here also in a way he personifies hope because he says that has knees and well (...) and then what else does he say? bleed $\backslash$ who bleeds? o what bleeds? what do you think/ this is now something very grammatical $\backslash$ what would the antecedent of this verb be/ I mean the subject the subject of the verb to bleed

Huma: they ((ellos "they" masculine)) no?

Researcher: is ellos but it can also be ellas ((they feminine: Knees is rodillas a feminine noun))

Huma: Yes

Researcher: and in this case what do you think? what is he talking about? only hope has clear knees\ they bleed $\backslash$

Huma: the knees no?

Researcher: the knees $\backslash$ and when can the knees bleed?

Huma: $\quad$ when you well when you fall or when you are hurt I mean

Researcher: when you fall or you are hurt $\backslash$ for example yes and and that in a metaphoric form do you think you can connect it with that of hope?

Huma: $\quad$ well I mean he says that hope is like like as you said before he perso personifies her ((it, third person)) you know/

Researcher: Yes

Huma: and that I mean I think that since it has those limits therefore hope therefore it bleeds because it has those limits it can't go I mean beyond

Researcher: [mjm] it can't go beyond $\backslash$ exactly $\backslash$ and and well hope is an espera/ ((which means both expectation and wait))

Huma: Yes

Researcher: it is as if you are waiting for something and well there you can think in this idea that you are saying that you fall $\backslash$ and as a consequence you bleed $\backslash$ and also maybe your knees can bleed if you are kneeling for a long time/

Huma: that too

Researcher: And

Huma: that you wait too much also because you expect too much $\backslash$ you know/ because if hope is like you wait for/expect something to happen what you what you want you know/ and and if/ if I you keep too long that hope at the end it is as if you were hurting yourself because you are also wasting a lot of time

The study shows that emotional response, and exploration of meaning about the world also happened in small group conversations about poems. Huma, Jaime, Ariadna, two other girls, and the researcher talked about the visual poem ${ }^{10}$ "L'empleat" (The employee). 
Figure 1. L'empleat (1989) by Joan Brossa (Barcelona, 1919-1998). By courtesy of the Fundació Joan Brossa

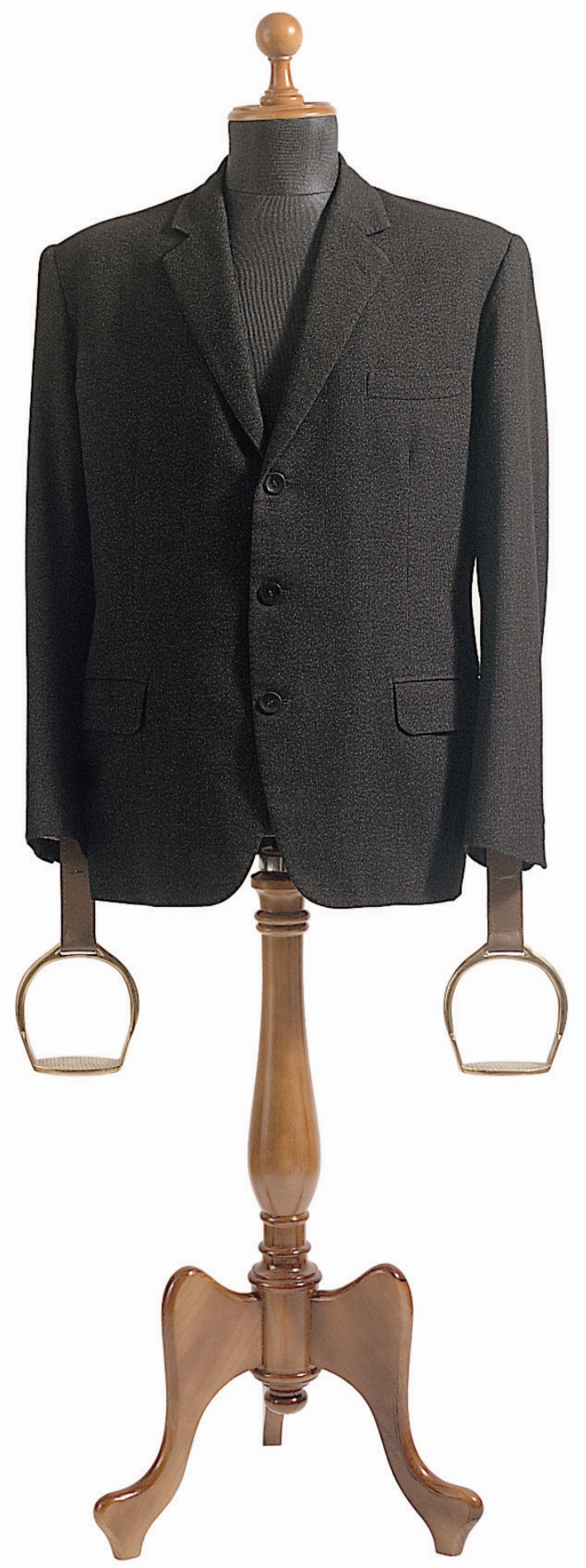

Copyright Fundació Joan Brossa

Their dialogue shows a joint meaning construction that goes from the description of the image to its metaphoric interpretation. This progression was also an ideological one, as students used the constructed meaning to critically think about the social distribution of power. In their conversation they showed growing engagement and enthusiasm (increased overlapping, 
interruptions, and laughter) which points at a shared and fulfilling lived-through aesthetic experience. Conversation also worked as an opportunity for students to improve their poetic literacy.

Researcher: (...) well let's go then to the suit with stirrups $\mid$ because many people liked it $\backslash(\ldots)$ what did you think? |

Girl 1: first I thought that was what a boss sees of his employee $\backslash$ a jacket and something that well a coat stand $\backslash$ for (???) whatever what may be missing something for also (???) for carrying an object/

Huma: well when I see this well it is the employee because I interpret I mean the jacket the employee wears and this is as if it made a facel because his eyes let's say and and I interpret as if it were his mustache $\backslash$ I don't know

Researcher: [aaa?] [surprised]

Ariadna: it is very visual?

Researcher: very visual $\backslash$ very visual $[$ laughing softly]

Ariadna: I interpret well that [Jaime interrupts] the fact that it is put on a coat stand as if it were a mannequin/ | it is something stat that is not? static is? It is it is/

Jaime: $\quad$ standstill

Researcher: without movement

Ariadna: it is something static no? it is that I mean as if how they treat the employee that goes $\backslash$ I mean they want an employee that goes wearing an jacket he is the typical rigorous that has to behave in a certain way at his work $\$ so it is marked on him and it is and he doesn't have openness to do his work he is very static $\backslash$ and he has and already he has a concept of how it must be this person facing situations/ that he can be either arrogant or very educated etcetera no? and this/ well treated like a horse $\backslash$ because he is he is the one lead by a superior no? o well I don't know I sayl

Researcher: well it can be because

Ariadna: he is

Researcher: the stirrups for what do we use them?

Jaime: $\quad$ of course [softly]

Huma: $\quad$ to step [softly]

Ariadna: a no for what do we use them?

Jaime: $\quad$ to place your feet pal

Researcher: to place your feet but also as a way to control/ because

Ariadna: [interrupting] that is $\backslash$ control

Researcher: you with stirrups go you can squeeze them $\backslash$ and with the reins you give direction $\backslash$ but with the the you spur it let's say so that it gets moving $\backslash$ and with the reins you go giving the direction $\backslash$ like (???)

Girl 2: it is that isn't it? it is like to have the power or to control/ [voices interrupt each other and overlap]

Ariadna: I think someone is controlling youl

Jaime: $\quad$ you are a piece of furniture $\backslash(. .$.$) you are a piece of furniture buddy and that's it they do what$ they want with you and that's it they control you they control your life \laughs and voices overlapped]

Ariadna had a leading role in the joint construction of meaning. She took an important step in moving the group exploration from a more literal consideration of the image to a metaphoric one. However, she did so because other students and the researcher prompted her with some world knowledge she didn't have (what stirrups are for). Contrary to what happened in her classes, neither Jaime nor Ariadna were reluctant to participate in collaborative work with classmates. The atmosphere of approval (Wood, Bruner, \& Ross, 1976) built in this relaxed out-of-class conversation facilitated the exploration of meaning and peer-mediation. 
The study, mainly through interview situations, opened spaces of approval that fostered student's engagement with poetry reading and conversational activities around it. To facilitate dialogues in the classroom was more challenging. However, one class activity that appeared to foster dialogic interaction was to write about one's own reading of a poem. As homework, students had to write a reflection about a poem they had previously chosen from a selection of poems prepared by the teacher and the researcher. They could also search for a poem at a couple of online platforms made available to them. In this case, the encounter of people's words (Bakhtin, 1981) was a form of mediated communication. As Rosenblatt (1978) points out, in this kind of communication the reader mediates others' discourses without an actual rejoinder. The following example shows that dialogic activity didn't happen in an actual conversation, but by reading and reflecting, and with the scaffolding offered by the prompt of the assignment (available on Appendix 2).

Jaime chose a poem called "Yo soy un pez, un pez" by leaving Spanish poet José Corredor-Matheos:

YO SOY UN PEZ, UN PEZ

Yo soy un pez, un pez que va por el jardín, tan libre como un árbol.

Y soy también un árbol, que tiene sus raíces en el cielo, como un pájaro.

Soy un pájaro, un pájaro, y son míos los cielos las aguas y la tierra. ¿Por qué, si soy un pez, un pájaro y un árbol, la angustia de ser hombre hace que todo me resulte, de pronto, tan extraño?

\section{AM A FISH, A FISH}

I'm a fish, a fish

that goes through the garden, as free as a tree.

And I'm also a tree, that has its roots in the sky,

like a bird.

I'm a bird, a bird, and the skies are mine the waters and the earth. Why, if I'm a fish, a bird and a tree, the anguish of being a man makes me, suddenly, see everything so strange?

In his reading activity Jaime perceived that the other with whom he was speaking was the author:

I have liked the poem because it was interesting to see how the author explained his feeling at that time using simple and easy examples to understand (...)

Like Huma, Jaime also responded to distinctive poetry devices, realizing that there were changes in the pattern established in the poem. The poem's final question presented an 
unpredictable twist to the meaning he was constructing. In his case, the effect of dehabituation was also explained in reference to himself, but pointing at his emotional experience. In his dialogue with the poem, nevertheless, Jaime encountered deviation and handled it without the need of any additional scaffolding:

(...) at the end the question he asked to himself which was the opposite of what he had mainly said. I would recommend it to all people who liked to read something that seems so predictable but at the end you see that was not as predictable and even makes you look silly.

His dialogue with what he perceived as the author's voice is lived in such a true manner that Jaime even criticized the author's example/idea. This suggests that in his meaning-making activity, Jaime lived through an emotional experience. He said:

This poem was written by José Corredor-Matheos in 2007. This poem because it was done very recently I think it represents the society we live at, that is, people are free, there is even excess of freedom in my opinion but there are obligations for the world to function, but it is true that in the poem he says to be free as a fish that goes through the garden, a tree that has its roots in the sky and a bird that owns the seas and the skies, but they still have responsibilities, different from the ones humans have but they still have responsibilities, so I don't think they were truly the best example, but if we look at the degree of responsibility we can indeed say that the animals and plants he mentions are freer as he explains them.

\section{Conclusion}

The evidence showed in this article gives insight into an understudied, and currently relevant, topic in the Catalan context. Although our findings have the limitation of coming mostly from interviews, they show activity (literary discussions) that also happens in classrooms or is relevant to them. Moreover, the study provides a useful theoretical framework for looking at these phenomena and activities. By combining a sociocultural understanding of reading and knowledge from the literary field, our study highlights two dimensions. First, the importance of mediation of the reader's response, in this case through dialogic activity, which happens in conversational and non-conversational situations. Second, the usefulness of understanding the particularities of poetry (e.g. deviation) as the object of activity. The consideration of these two dimensions could also be valuable for teachers interested in using poetry in their classes.

Lastly, Huma, Ariadna and Jaime represent the cultural and linguistic diversity encountered in many public schools. They also represent different levels of performance in their Language and Literature classes. These differences, that often materialize as disadvantage in the school system, were not present in what we saw in our study. Dialogue, and the allocation of time for meaning exploration, gave opportunities to all three students and the teacher to have fulfilling poetry reading experiences. 


\section{References}

Aliagas, C. (2011). Llegir en temps de lleure. Estudi de cas d'una colla d'adolescents amb el virus de la desafecció lectora. Articles de Didàctica de la Llengua i la Literatura, 53, 45-57.

Aliagas, C., Fernández, J.A. \& Llonch, P. (2016). Rapping in Catalan in class and the empowerment of the learner. Language, Culture and Curriculum, 29 (1), 73-92.

DOI: https://doi.org/10.1080/07908318.2016.1132658

Bakhtin, M.M. (1981). The dialogic imagination (M. Holquist, Ed., C. Emerson \& M. Holquist, Trans.). Austin, TX: University of Texas Press.

Ball, A. \& Freedman, S. W. (2004). Ideological becoming: Bakhtinian concepts to guide the study of language, literacy, and learning. In A. Ball \& S. W. Freedman (eds.), Bakhtnian perspectives on language, literacy, and learning (pp. 6-75). Cambridge: Cambridge University Press. DOI: https://doi.org/10.1017/cbo9780511755002

Brossa, J. (2005). L'empleat. In G. Bordons (dir.), Joan Brossa, desde Barcelona al Nuevo Mundo (p. 148). Barcelona: Institut Ramon Llull \& Fundació Joan Brossa.

Bruner, J.S. (1986). Actual minds, possible worlds. Cambridge, MA: Harvard University Press. DOI: https://doi.org/10.1176/ps.38.6.676

Calsamiglia, H. \& Tusón, A. (1999). Las cosas del decir. Barcelona: Ariel.

Cambra, M. (2003). Une approche ethnographique de la classe de langue. Paris: Didier.

Colomer, T. (1991). De la enseñanza de la literatura a la educación literaria. Comunicación, Lenguaje $\quad y \quad$ Educación, 21-31. 9, DOI: https://doi.org/10.1080/02147033.1991.10820954

Colomer, T. (1996). La didáctica de la literatura: temas y líneas de investigación e innovación. In: Lomas, C. (ed.), La educación lingüistica y literaria en la enseñanza secundaria (pp.123-142) Barcelona: ICE, Universitat de Barcelona y Horsori.

Colomer, T. (coord.) (2008). Lectures adolescents. Barcelona: Graó.

Colomer, T. (2009). L'escola fa o desfá joves lectors? Faristol (Consell Català del Llibre Infantil i Juvenil), 63, 8-10.

Corredor-Matheos, J. (2007). Un pez que va por el jardín. Barcelona: Tusquets Editores

Eva-Wood, A. L. (2008). Does feeling come first? How poetry can help readers broaden their understanding of metacognition. Journal of Adolescent \& Adult Literacy, 51 (7), 564576. DOI: https://doi.org/10.1598/jaal.51.7.4

Fowler, R. (1996). Linguistic criticism. $2 d$ ed. Oxford: Oxford University Press. 
Gelman, J. (1959). El juego en el que andamos. Buenos Aires: Nueva Expresión.

Hanauer, D. I. (1998). Reading poetry: An empirical investigation of formalist, stylistic, and conventionalist claims. Poetics Today, 19, 565-580. DOI: https://doi.org/10.2307/1773260

Harker, W. J. (1994). "Plain sense" and "poetic significance": Tenth-grade readers reading two poems. Poetics, 22, 199-218. DOI: https://doi.org/10.1016/0304422x(94)90005-1

Manresa, M. (2007). Lectures dels adolescents: entre la tria personal i la selecció escolar. Articles de didàctica de la Llengua i la Literatura, 41, 71-86.

Manresa, M. (2009). Els hàbits lectors dels adolescents. Efectes de les actuacions escolars en les pràctiques de lectura ( $\mathrm{PhD}$ thesis). Universitat Autònoma de Barcelona.

Manresa, M. (2012). La construcción de identidades a través de la lectura adolescente: una pauta para la actuación escolar. Literatura infantil y juvenil e identidades / Literatura para a infãncia e juventude e identidades (pp. 327-345). Vigo/Braga: ANILIJELOS/CIEC-Universidade do Minho.

Mendoza, A. (2004). La educación literaria. Bases para la formación de la competencia literaria. Archidona: Aljibe.

Miall, D. S. (2006). Literary reading: Empirical \& theoretical studies. New York: Peter Lang.

Munita, F. (2014). El mediador escolar de lectura literaria. Un estudio del espacio de encuentro entre prácticas didácticas, sistemas de creencias y trayectorias personales de lectura ( $\mathrm{PhD}$ thesis). Universitat Autònoma de Barcelona.

Munita, F. (2017). La didáctica de la literatura: hacia la consolidación del campo. Educação e Pesquisa, 43 (2), 379-392. DOI: https://doi.org/10.1590/s1517-9702201612151751

Nystrand, M. (1997). Dialogic instruction: When recitation becomes conversation. In M. Nystrand, A. Gamoran, R. Kachur, \& C. Prendergast (eds.), Opening dialogue (pp.129). New York: Teachers College Press.

Palou, J. (2008). L'ensenyament i l'aprenentatge del català com a primera llengua a l'escola. Creences $i$ actuacions dels mestres amb relació a les activitats de llengua oral a l'etapa primària. Barcelona: Institut d'Estudis Catalans.

Peskin, J. (2010). The development of poetic literacy during the school years. Discourse Processes, 47, 77-103. DOI: https://doi.org/10.1080/01638530902959653 
Reyes, L. (2011). Fer lectors en un context advers. Articles de Didàctica de la Llengua i la Literatura, 53, 58-67.

Rosenblatt, L.M. (1978). The reader, the text, the poem: The transactional theory of the literary work. Carbondale: Southern Illinois University Press.

Rosenblatt, L. M. (2004). The transactional theory of reading and writing. In R.B. Ruddell \& N. J. Unrau (eds), Theoretical models and processess of reading, 5th edition (pp.1363-1398). Newark, DE: International Reading Association. DOI: https://doi.org/10.1598/0872075028.48

Sanz, G. (2011). Escritura joven en la red. Textos de Didáctica de la Lengua y la Literatura, $57,30-45$.

Wells, G. (2002). The role of dialogue in activity theory. Mind, Culture, and Activity, 9 (1), 43-66. DOI: https://doi.org/10.1207/s15327884mca0901_04

Wertsch, J. (2007). Mediation. In H. Daniels, M. Cole, \& J. Wertsch (eds.), The Cambridge companion to Vygotsky (pp.178-192). Cambridge: Cambridge University Press. DOI: https://doi.org/10.1017/ccol0521831040.008

Widdowson, H. G. (1992). Practical stylistics: an approach to poetry. Oxford: Oxford University Press.

Wood, D., Bruner, J.S., \& Ross, G. (1976). The role of tutoring in problem solving. Journal of Psychology and Psychiatry, 17. DOI: https://doi.org/10.1111/j.14697610.1976.tb00381.x

Woods, P. (1986). Inside schools. London: Routledge.

\section{Notes}

${ }^{1}$ In Spanish this field is called Didáctica de la literatura. There isn't an equivalent term in English, but it can be translated as "The teaching of literature".

${ }^{2}$ As understood in Bakhtin's concept of ideological becoming.

${ }^{3}$ Vygotsky's maxim (Wertsch, 2007).

${ }^{4}$ Tamazight Tarifit (Riffian Bereber).

${ }^{5}$ In general, in the Spanish/Catalan high school context the prevailing approach to the teaching of poetry emphasizes stylistic analysis of works by canonic authors presented in a chronological manner with consideration of their historical situations. Their aim is to prepare students who will continue onto the university-track, after mandatory high school, for the "PAU" (Prueba de Admisión Universitaria), a high-stakes university admission exam. ${ }^{6}$ All the translations of poems and transcripts are mine, except for the one of the poem "Límites" which I did with the help of a former colleague, Michael Holt. I simplified transcription conventions due to phonetic differences between Spanish and English. An explanation of the conventions used can be found on Appendix 1.

${ }^{7}$ The original data is in Spanish. All the original excerpts showed can be found on Appendix 2. They are organized following the same order they have in the body of the article.

${ }^{8}$ Translated in the poem as "clear". However, "nítida" is a less common and more specific word than "clara" (also "clear" in English). Huma's home language is not Spanish, and she has been schooled in Catalan. As a consequence, vocabulary is a challenge for her in the reading of literary works in her Spanish class.

${ }^{9}$ Referring to Vygotsky's theory. 
${ }^{10}$ Regarding the aims of the study, we didn't find significant differences between students' responses to written and visual poetry.

\section{Appendix 1}

\section{TRANSCRIPTION CONVENTIONS}

Adapted from Calsamiglia and Tusón (1999), and Palou (2008)

$\begin{array}{ll}\mid & \text { pause } \\ ? & \begin{array}{l}\text { interrogative tone } \\ \text { descending tone }\end{array} \\ / & \text { ascending tone } \\ (? ? ?) & \text { word(s) not understood } \\ {[\quad]} & \text { non lexical phenomenon } \\ (()) & \text { research's comment } \\ (\ldots) & \text { skipped part } \\ \text { Italics } & \text { Used to highlight what is being mentioned in the article. }\end{array}$

\section{Appendix 2}

\section{ORIGINAL EXCERPTS}

\section{CONVERSATION WITH HUMA ABOUT THE POEM "LÍMITES”}

1

Investigadora: el poema cuando tú lo leíste o te lo leí yo en primer lugar ¿qué dirías tú que te pasa? ¿te hace sentir algo? ¿te hace pensar en algo? [e::] ¿te hace reflexionar? te que ¿qué te hace? digamos

Huma: es como si me hiciera o sea un poco de reflexionar porque $\mid$ [em] en parte tienes razón o sea por qué no sé porque he empezado- o sea me ha venido como en la mente el ejemplo por qué dicen que si una persona te (???) a lo mejor pa un- para todo el mundo e eso que es amor $\backslash$ a lo mejor no es amor $\backslash$ a lo mejor pa ti el amor es diferente $\backslash$ es hasta que e esa per-ese que es tu sentimiento de que lo quieres no que (lo) te atraiga $\backslash$ y por ejemplo si en lo de la sed y del agua pues por ejemplo si por qué hasta aquí es la sed y aquí y hasta aquí es el agua $\backslash$ por ejemplo pa ti so- uno porque la dicen cuando tú tienes la la boca digamos deshidratada $\backslash$ eso es sed $\backslash$ a lo mejor tú no sientes que eso es sed/ a lo mejor cuando tú tienes sed es cuando no te has criado no sé diferente que los demás $\backslash$ por qué to siempre tenemos que estar como todos iguales/

2

Huma:

sí es como que | un poco yo creo que está como indignado diciendo ¿pero quién lo dijo? sabes/ porque cada uno es libre de $\mid$ o sea de marcar sus límites cada uno sus límites son diferentes de las demás personas pero él es como si se cuestiona o sea quién fue el que puso digamos el límite (...) que va repitiendo y da una sonoridad $\backslash$ pero lo que no entiendo es [con leve risa] esto la última

Investigadora: ¿no entiendes los últimos versos?

Huma: [en voz baja] sí

3

Huma:

sí porque cuan- la primera vez que lo leí pues entendí esto $\backslash$ entonces cuando leí el último verso pues me quedé como descolocada $\backslash$ sino que qué me quiere decir ahora

4

Huma: $\quad$ sí o sea $\quad$ pues que las- o sea eso de la que tú dices la esperanza o sea que e es como si la esperanza también tiene límites ¿no? porque tú dic- tú también la esperanza la puedes o sea tengo la esperanza de que de algo ma más o sea o sea aquí te está diciendo que la esperanza también tiene o 
Investigadora:

Huma:

Investigadora:

Huma:

Investigadora:

Huma:

Investigadora:

Huma:

Investigadora:

Huma:

Investigadora:

Huma:

Investigadora:

Huma:

Investigadora:

Huma:

Investigadora: $\quad \mathrm{y}$

Huma: sea límites $\backslash$ porque ya que no es la esperanza de ir más allá de los límites sino que incluso la esperanza cuando tú esperas algo lo esperas dentro de los límites $\backslash$

[mjm] de ciertos límites $\backslash$ claro $\backslash$ claro $\backslash y$ también aquí de de alguna manera personifica la esperanza porque dice tiene las rodillas y bueno (...) entonces $\backslash$ y después ¿qué más dice? sangran $\backslash$ ¿quiénes sangran? o ¿qué sangra? ¿¿cuál crees tú/ eso ya es una cosa muy gramatical $\backslash$ que sería el antedecente de de este verbo/ o sea el el sujeto $\backslash$ el sujeto del verbo sangrar

ellos ¿no?

es ellos pero puede ser ellas también

sí

y en este caso ¿qué crees tú? ¿ ¿de qué está hablando? sólo la esperanza tiene las rodillitas las rodillas nítidas \sangran\

las rodillas ¿no?

las rodillas $\backslash$ y po- ¿cuándo pueden sangrar las rodillas?

cuando te- o sea cuando te caes o cuando te haces daño o sea

cuando te caes o te haces daño $\backslash$ por ejemplo sí y [e::] | y eso de manera metafórica ¿crees tú que lo puedes relacionar con lo de la esperanza?

que o sea que que él dice que la esperanza es como como dijiste tú anteriormente que la la per personifica sabes/

sí

y que a o sea yo creo que al tener como u- esos límites pues la esperanza pues también sangra porque tiene esos límites que no puede o sea ir más allá $\backslash$

[mjm] no puede ir más allá $\backslash$ exacto $\backslash y \mid$ y bueno la esperanza es una espera cierto/

sí

es como que tú estás esperando algo y bueno ahí puedes pensar en esa idea que tú dices que | te caes $\backslash$ y por eso sangras $\backslash y$ también a lo mejor te pueden sangrar las rodillas si estás mucho tiempo arrodillada/

también\

$\mathrm{y}$

que esperas mucho también porque esperas mucho $\backslash$ sabes/porque si es la esperanza es como esperas que que pase lo que- lo que tú quieres sabes/ pero y si/ si yo- llevas mucho tiempo con esa esperanza al final ya es como si te estuvieras haciendo daño porque también estás perdiendo mucho tiempo\}

\section{GROUP CONVERSATION ABOUT THE POEM “L'EMPLEAT”}

Investigadora: (...) bueno vamos entonces al del traje con los estribos $\backslash$ | a ver porque éste a varias personas les les les gustó $\backslash$ Alumna 1 ¿tú qué pensaste?

Alumna 1: $\quad$ para empezar pensé que era pues lo que un jefe ve de su empleado $\backslash$ una chaqueta y algo que bueno un perchero $\backslash$ también para (???) cualquier cosa lo de quizás faltaría una cosa para que además (???) para que llevara un objeto

Huma: pues que yo cuando veo esto pues es el empleado porque yo interpreto o sea la chaqueta que lleva el empleado y esto es como si formara la cara $\backslash$ porque es los ojos digamos y y yo lo interpreto como si fuera el bigote $\backslash$ no sé $\backslash$

Investigadora: $\mathrm{a}:$ : [con sorpresa]

Ariadna: ¿es muy visual?

Investigadora: $\quad$ muy visual $\backslash$ muy visual $\backslash$ [sonriendo]

Ariadna:

yo interpreto pues que [Jaime interrumpe] el hecho de que lo ponga en un perchero como fuera un maniquí/ | ¿es algo esta que no es? ¿estático es que está? Está está

Jaime: Investigadora: detenido

Ariadna:

\section{sin movimiento〉}

¿es algo estático no? Y es que las o sea como que cómo tratan al empleado que va con $\backslash$ o sea no lo van a un empleado que va con americanas es el típico rigoroso $\backslash$ que tiene que comportarse de una determinada forma para su trabajo $\backslash$ entonces lo tiene muy marcado y es y no tiene ampliación para hacer su trabajo es muy es estático $\backslash$ y hay y ya:: hay su o sea ya hay su concepto de cómo debe ser esta persona delante de las situaciones/ que puede ser o arrogante o muy educada etcétera ¿no? Y esto pues es lo trata como caballo\porque es que es el que está con conducido por un superior ¿no? O bueno no sé yo lo digo yo\}

Investigadora: bueno puede ser porque

Ariadna: está

Investigadora: los estribos ¿para qué los usamos? 


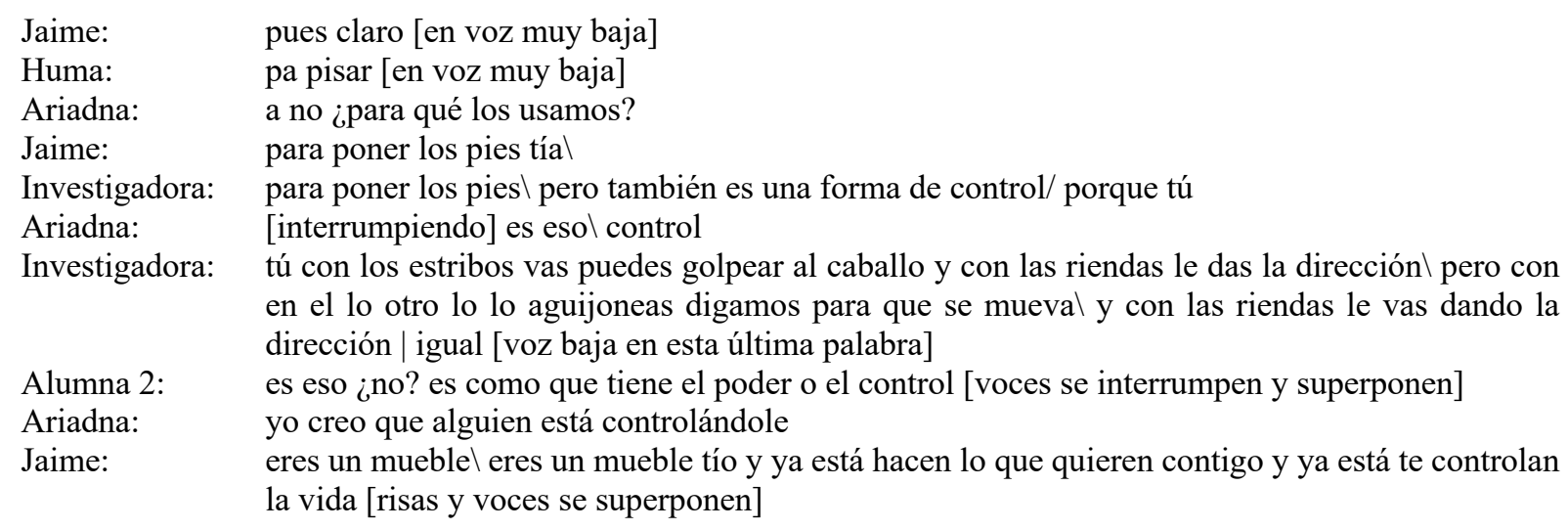

\section{JAIME'S WRITTEN REFLECTION}

1

El poema en sí me ha gustado ya que era interesante ver cómo el autor explicaba su sentimiento en ese momento poniendo poniendo ejemplos sencillos y fáciles de entender.

\section{2}

finalmente la pregunta que se hacía a sí mismo que era lo contrario a lo que él había dicho principalmente. Se lo recomendaría a todas las personas que les guste leer una cosa que parece tan predecible pero que al final ves que no era tan predecible e incluso te hace parecer tonto.

\section{3}

Este poema fue escrito por José Corredor-Matheos en 2007. Este poema al haber estado hecho tan recientemente creo que representa la sociedad en la que vivimos, es decir, la gente es libre, incluso hay excesos de libertad en mi opinión pero hay obligaciones para que el mundo funcione, pero sí que es verdad que en el poema él dice ser libre como un pez que va por el jardín, un árbol que tiene sus raíces en el cielo y un pájaro que son suyos los mares y los cielos, pero todo y eso ellos tienen responsabilidades, diferentes a las de los humanos pero igualmente tienen responsabilidades, entonces tampoco creo que fueran del todo el mejor ejemplo, pero si miramos el grado de responsabilidad sí que podemos decir que animales y plantas que cita sí son más libres como los explica.

\section{Appendix 3}

\section{GUIDELINES FOR THE INDIVIDUAL WRITTEN REFLECTION}

We are interested in learning about your individual reading experience. Therefore, we will specially appreciate your authenticity.

Comment on what the poem has made you think, feel, remember, imagine, etc. About the meaning that you give to the poem.

Explain why you like this poem, or not. Would you recommend its reading to anyone? Why?

Answer the following question: Do you think that sharing its discussion with your classmates has been beneficial to you? Explain briefly.

If you want, connect your ideas and feelings with contextual information about the poem. For instance, the author, the time period/historical moment, etc.

\section{PAUTAS PARA LA REFLEXIÓN ESCRITA (TRABAJO ESCRITO INDIVIDUAL)}

En este trabajo interesa conocer tu experiencia personal de lectura, por lo tanto, se valorará especialmente tu autenticidad.

Refiérete a lo que el poema te ha hecho pensar, sentir, recordar, imaginar, etc. Al sentido que le das al poema.

Expresa por que te ha gustado, o no, este poema. ¿Se lo recomendarías alguien? ¿por qué?

Responde lo siguiente: ¿crees que compartir su discusión con tus compañeros te ha aportado algo? Explícalo un poco.

Si quieres, puedes relacionar tus ideas y sensaciones con información sobre el contexto del poema, es decir, sobre el autor, la época, etc. 


\section{Author's information:}

Daniela Cavalli holds a M.A. (2010), and a Ph.D. (2016) in The Teaching of Language and Literature from the University of Barcelona. She is a Spanish Lecturer at the University of Pennsylvania. Her area of interest is literary education, particularly the role and use of poetry in educational settings. She has published articles about the perception and response to visual Catalan poetry; the use of reflexive writing to improve the poetry reading experience; and the challenges and opportunities brought about by the teaching of poetry. She has been a member of the University of Barcelona's research group POCIÓ (Poesia i Educació) since 2009. She has taught Spanish language and literature in preparatory high schools and in college at different institutions in Chile and the US. She has also taught within the field of The Teaching of Language and Literature in undergraduate and graduate courses at the University of Barcelona.

E-mail: dcavalli@sas.upenn.edu

Para citar este artículo:

Cavalli, D. (2019). How dialogues facilitate high school students' responses to poetry. Bellaterra Journal of Teaching \& Learning Language \& Literature, 12(3), 26-43. DOI: https://doi.org/10.5565/rev/jt13.844 